\title{
REPRESENTASI NILAI ISLAMI PERAN ORANG TUA DALAM MENDAMPINGI ANAK DIFABEL PADA ANIMASI NUSSA
}

\author{
Faishal Abyan Hanif \\ Universitas Ahmad Dahlan Yogyakarta \\ faabyan01@gmail.com \\ Difa'ul Husna \\ Universitas Ahmad Dahlan Yogyakarta \\ difaul.husna@pai.uad.ac.id \\ Unik Hanifah Salsabila \\ Universitas Ahmad Dahlan Yogyakarta \\ unik.salsabila@pai.uad.ac.id
}

\begin{abstract}
The role of parents in carrying out learning for children's lives in the future is very important, the absence of this parent's role can result in negative consequences that can affect it, especially children with special needs. On the other hand, currently changes in the learning system due to the pandemic have resulted in the government adopting a distance learning policy so that teachers have to innovate more in developing strategies to carry out learning activities, besides that in this new learning system, parents must participate in accompanying children's learning. This is something new for some parents because previously children were entrusted to formal and non-formal institutions, as a result, many parents were confused about how to assist their children in learning. In this study, it discusses the role of parents in accompanying children without being separated from Islamic values which aim to make it easier to provide a description of parents about their roles in assisting children to learn. The method used in this research is a qualitative approach using representation theory. The result of this research is to describe the role of parents, especially mothers, in accompanying children to study at home and become role models for children. This study also reveals that the main character of the animated film is a child with disabilities. Meanwhile, the Islamic values presented are instilling a sense of gratitude, responsibility and sharing with others.
\end{abstract}

Keywords: Islamic education, technology of education, disability, the role of parents 


\begin{abstract}
Abstrak
Peran orang tua dalam melakukan pembelajaran untuk kehidupan anak kedepan sangatlah penting, ketiadaan peran orang tua ini bisa mengakibatkan konsekuensi negatif yang dapat mempengaruhinya, apalagi anak yang mempunyai kebutuhan khusus. Di sisi lain saat ini perubahan sistem pembelajaran dengan adanya pandemi mengakibatkan pemerintah mengambil kebijakan pembelajaran jarak jauh sehingga menjadikan guru harus lebih berinovasi dalam menyusun strategi untuk menjalankan kegiatan pembelajaran, selain itu dalam sistem pembelajaran yang baru ini menjadikan orangtua harus ikut berpartisipasi dalam mendampingi belajar anak, hal ini merupakan sesuatu yang baru bagi sebagian orangtua karena sebelumnya anak dititipkan pada lembaga formal maupun nonformal, akibatnya tidak sedikit orang tua yang bingung bagaimana cara dalam mendampingi anak belajar. Dalam penelitian ini membahas peran orang tua dalam mendampingi anak dengan tidak terlepas dari nilai islami yang bertujuan untuk memudahkan dalam memberikan gambaran orang tua mengenai perannya dalam mendampingi anak belajar. Metode yang digunakan dalam penelitian ini adalah metode pendekatan kualitatif dengan menggunakan teori representasi. Hasil dari penelitian adalah menggambarkan peran orang tua terkhusus ibu dalam mendampingi anak belajar di rumah dan menjadi sosok teladan bagi anak, dalam penelitian ini mengungkapkan juga bahwa tokoh utama dari film animasi tersebut merupakan anak difabel. Sedangkan nilai-nilai islami yang dipresentasikan adalah menanamkan rasa bersyukur, tanggungjawab dan berbagi terhadap sesama.
\end{abstract}

Kata kunci: pendidikan islam, teknologi pendidikan, disabilitas, peran orang tua

\title{
Pendahuluan
}

Adanya virus corona atau yang disebut juga covid-19 (corona virus desease) yang sudah menyebar di seluruh dunia. WHO menyatakan peristiwa ini sebagai pandemi. Virus ini pertama kali berasal dari China, di kota Wuhan. Data terkini 56 juta kasus dari 219 negara yang dinyatakan positif pada pertengahan November 2020. ${ }^{1}$ data tersebut terus berkembang baik jumlah yang terpapar, sembuh dan meninggal dunia.

Selama pandemi berlangsung, kegiatan pembelajaran dilakukan secara daring. Model pengganti pembelajaran luring ini hampir diterapkan di seluruh belahan dunia begitu juga di Indonesia, namun sejauh ini belum dilakukan secara serentak dengan pemerataan kurikulum yang baku. Sistem pembelajaran baru yang

1https://www.worldometers.info/coronavirus.(worldometer.info diakses pada 26/12/2020

\section{Vol. 1 No. 2 ( D e se mber, 2020 ) Page 107}


dijalankan oleh pemerintah dalam mencegah penularan virus covid-19 yakni pembelajaran jarak jauh sehingga kegiatan pembelajaran yang biasanya dilakukan oleh satuan pendidikan, beralih pada satuan keluarga, yang artinya rumah menjadi sentral kegiatan bagi peserta didik didalam keluarga.

Pada perakteknya pendidikan yang utama sebenarnya dilakukan didalam keluarg, covid-19 mengembalikan tugas edukatif pada kedua orang tua sebagai orang pertama kali bertanggungjawab terhadap pendidikan anak.Astita mengatakan bahwa kedua orang tua adalah guru utama anak, karena sejak awal anak melihat, mengagumi dan meniru prilaku anaknya.Jadi tidak salah bila keluarga menjadi madarastul ula dan gurunya kedua orang tua yang berpengaruh besar terhadap pembentukan kepribadian anak. ${ }^{2}$

Sebagian orang tua mengatakan bahwa sistem pembelajaran baru yang dilakukan di rumah dengan bimbingannya dirinya cukup menyenangkan karena dapat mempererat hubungan dengan anaknya, tetapi tidak sedikit juga orang tua yang mengeluhkan sebab memiliki kendala seperti kurang pahamnya orang tua dengan materi, sehingga terkadang terbawa emosi, sulitnya menumbuhkan semangat belajar ketika di rumah, tidak memiliki waktu yang cukup untuk mendampingi anak belajar dan juga terkait jangkauan layanan internet. Hal ini mengakibatkan sebagian orang tua meminta untuk kegiatan pembelajaran dikembalikan kepada pihak sekolah dengan cara tatap muka.

Dalam upaya mencegah dan menurunkan angka positif covid maka kebijakan pemerintah mengenai pembelajaran harus tetap dijalankan, dan hal ini dapat dipahami bahwa, masa pandemi ini menjadi rumah sebagai ruang kelas dimana orang tua bertanggungjawab sepenuhnya didalam pembelajaran. Dari pada itu maka dalam pembelajaran di rumah setidaknya ada empat peran orang tua selama pembejaran daring diantaranya sebagai pembimbing, fasilitator, motivator, dan Orang tua sebagai pengaruh atau director. ${ }^{3}$

Dengan memanfaatkan perkembang teknologi dan untuk mendukung pembelajaran jarak jauh, Penelitian ini berupaya menjawab bagaimana agar orang tua kembali memahami dan melakukan perananya dalam mendidik anak. Tinjauan

\footnotetext{
${ }^{2}$ Wida Astita. Peran Orang Tua Dalam Mendidik Akhlak Anak Di Desa Bangun Jaya Kecamatan Sungkai Utara Lampung Utara. (Lampung Jurusan Pendidikan Agama Islam IAIN Raden Intan,2016), hal.41

3 Nika Cahyati,Peran Orang Tua Dalam Menerapkan Pembelajaran di Rumah Saat Pandemi Covid 19. (Jurnal Golden Age, Universitas Hamzanwadi, 04(1),2020), Hal.155 
pustaka yang digunakan adalah literatur artikel ilmiah dan film animasi web series Nussa dan Rara yang merupakan sebuah film animasi bernuansa islami dibungkus dengan karakter lucu anak umur 5 tahun namun sudah cukup cakap dengan ilmu keislamannya, didalam animasi Nussa terdapat banyak aktifitas pendidikan yang dilakukan orang tua di dalam rumah. Tujuan dari penelitian ini agar orang tua mendapat gambaran peran yang dapat dilakukannya terkhusus ibu sebagai orang tua dalam mendampingi anak belajar di rumah.

\section{Tinjauan Literatur}

\section{Semiotika dan Komunikasi}

Manusia pada hakekatnya sebagai mahluk sosial dan individual. Sebagai mahluk sosial tentu mereka senantiasa akan selalu berinteraksi dengan manusia lainnya. Perjumpaan interaksi tersebut akan mendorong kontak langsung dan tidak langsung melalui saluran komunikasi.dari komunikasi itulah kemudian terjadi pertukaran makna antar subjek-subjek komunikan dan komunikator.untuk menghasilkan kesepemahaman makna maka dibutuhkan tanda (sign) yang dapat bersumber dari setiap kata, nada, sikap atau ekspresi dalam setiap perkataan. Begitu pula saat seseorang berinteraksi dengan lingkungan sekitarnya, akan banyak tanda-tanda yang dapat melahirkan makna. Tanda-tanda itu mendorong terciptanya persepsi dan konsepsi. Begitu vitalnya peran tanda dalam pemaknaan pada interaksi manusia, maka kemudian lahirlah ilmu yang disebut semiotika.

Kata semiotika berasal dari bahasa yunani, semeion yang berati tanda atau seme yang berarti penafsir tanda. Konsep dasar dari semiotik adalah ilmu yang mengambil makna dari sebuah tanda yang tentunya relevan dengan kebutuhan masyarakatnya. ${ }^{4}$ Umberto Eco mengatakan bahwa semiotika berhubungan dengan suatu tanda yang tidak hanya mencul dalam percakapan sehari-hari, tetapi tandatanda itu bisa berupa kata, grafis, suara, gerak tubuh dan objek yang dapat dilihat.para ilmuan semiotik kontemporer melihat bahwa tanda-tanda tidak terpisah dari bagian sistem semiotik seperti media dan genre. Ilmuan semiotik mengkaji bagaimana makna itu diproduksi dan bagaimana realitas dipresentasikan. ${ }^{5}$

\footnotetext{
${ }^{4}$ Indiwan Seto Wahyu Wibowo, Semiotika Komunikasi - Aplikasi Praktis Bagi Penelitian Dan Skripsi Komunikasi, (Jakarta : Penerbit Mitra Wacana Media, 2013), hal,7

5 Daniel Chandler, Semiotics The Basics, (Perancis: Taylor \& Francis e-Library, 2007), Cet. II, hal. 2
} 
Dalam kehidupan sehari-hari terjadi pertukaran tanda yang menghasilkan makna, bahkan dalam memahami dunia.Cara seseorang bertindakpun juga merupakan bagian dari cara mereka dalam menafsirkan tanda.Begitu penting ilmu tanda untuk menghasilkan makna kehidupan yang lebih berarti. Tentu melalui semiotika seseorang dapat membangun dan memproduksi pemaknaan yang lebih konstruktif untuk kepentingan peradaban masa depan yang lebih baik.

Sedangkan komunikasi dalam bahasa inggris, communicate berarti untuk bertukar pikiran, perasaan dan informasi. Menurut Stuart komunikasi berarti pertukaran simbol, pesan antara individu-individu, seni untuk mengekspresikan gagasan. ${ }^{i}$ Dari uraian tersebut arti dari komunikasi tidak terlepas dari makna pertukaran simbol baik verbal maupun non-verbal. Simbol atau tanda verbal yang dimaksud bisa berupa bahas lisan atau tulisan. Sementara non-verbal seperti gerakgerik, suara serta mimic. ${ }^{6}$

Jelas semiotika dan komunikasi bagian penting yang tidak terpisahkan dalam kehidupan manusia yang beradab, melalui jalinan komunikasi persoalan-persolan kehidupan dapat diselesaikan dengan baik, banyak hal yang dapat memicu persoalan sosial salah satunya karena terjadi penyumbatan dan mecet pada saluran-saluran komunikasi yang diakibatkan oleh ketidak sepemahaman dan mis komunikasi. Dengan komunikasi yang baik serta penafsiran yang konstruktif itu maka penyumbatan dan kesalahpahaman dapat diatasi, begitu pentingnya komunikasi yang baik di dalam ruang pendidikan, keluarga dan ruang sosial.

\section{Peran Orang Tua pada Anak dalam Perspektif Islam}

Guru merupakan pendidik ketika anak berada di lingkungan sekolah (formal), sedangkan orang tua adalah pendidik anak selama berada di lingkungan keluarga (informal) atau di rumah ${ }^{7}$ Orang tua merupakan pendidik pertama atau dasar utama pendidikan bagi anaknya, maka sudah barang tentu sebagai pendidik orang tua mempunyai banyak peranan. Peranan merupakan kata yang berasal dari "peran" yang berarti pemain sandiwara, kemudian kata peran ketika sudah ditambah dengan akhiran "an" menjadi peranan memiliki arti sesuatu yang menjadi bagian atau memegang pimpinan yang utama. 8

\footnotetext{
${ }^{6}$ Stuart. 1983. dalam Vardiansyah. 2004:3

7 Fakhriyatus. Dan Moral Pada Masapandemidi Tk Al-Hidayah Lumajang. Jurnal Pengembangan Nilai agma dan moral. 2020. Vol. 1. No. 1. Hal 50

8 Poerwadarminta. Kamus Besar Bahasa Indonesia, Jakarta : Balai Pustaka, 1991, hal 735 
Soekanto mengemukaan pendapat pertama, peranan meliputi norma-norma yang dihubungkan dengan posisi atau tempat seseorang dalam masyarakat. Peranan dalam arti ini merupakan rangkaian peraturan-peraturan yang membimbing seseorang dalam kehidupan. Kedua, peranan adalah suatu konsep tentang apa yang dapat dilakukan oleh individu dalam masyarakat sebagai organisasi dan ketiga, peranan juga dapat dikatakan sebagai perilaku individu yang penting bagi struktur masyarakat. 9

Sedangkan Usman mengartikan peranan sebagai serangkaian tingkah laku yang saling berkaitan yang dilakukan oleh seseorang dalam situasi dan kondisi tertentu yang mengarah kepada perbaikan dalam perubahan tingkah laku seseorang. ${ }^{10 j a d i}$ jelas peranan orang tua dalam konteks pendidikan informal dalam keluarga berorientasi pada transfer of value atau transmisi kebudayaan dari orang tua kepada anaknya.

Dari berbagai pendapat diatas dapat diartikan bahwa peranan merupakan suatu tinndakan, aktivitas atau serangkaian tingkah laku yang menjadikan aturan dan norma sebagai acuan dalam melaksanakanya. Peranan ini menuntut agar seseorang aktif dalam mengemban tugas dan tanggung jawabnya.

Mengenai tanggung jawab orang tua dalam al-quran surat At-Tahrim ayat 6 berbunyi:

Hai orang-orang yang beriman, peliharalah dirimu dan keluargamu dari api neraka yang bahan bakarnya adalah manusia dan batu; penjaganya malaikat-malaikat yang kasar, keras, dan tidak mendurhakai Allah terhadap apa yang diperintahkan-Nya kepada mereka dan selalu mengerjakan apa yang diperintahkan.

Secara spesifik memang tidak dijelaskan tanggung jawab orang tua terhadap anaknya dalam ayat tersebut namun sebagai seorang yang beriman dan mengerti tentang Al-quran dapat dipahami dengan mudah, maka tidak salah jika Al-Quran kitab pendidikan, banyak petunjuk dan pedoman-pedoman untuk mendidik anak. Al-Quran telah menjadi literatur yang sangat relevan dengan situasi dan kondisi zaman bagaimana orang tua menjadi guru utama di dalam Al-Quran, baik berkaitan dengan materi ajar, tujuan, media dan metode yang telah digambarkan Al-Quran.

\footnotetext{
9 Soejono, Soekamto, Sosiologi Suatu Pengantar, Jakarta : CV. Rajawali Press, 19906 10 Muhammad Uzer, Usman. Menjadi Guru Profesional,.Bandung : Remaja Rosdakarya, 1995, hal 30
} 
Menurut Quraish Shihab dalam tafsirnya al-Misbah menjelaskan bahwa orang tua dalam mendidik anaknya pertama, Memberikan pendidikan tauhid serta menjauhkan dari perbuatan dzalim. Dalam Islam pendidikan tauhid atau pengenalan akan keesaan Allah adalah langkah pertama yang harus diusahakan oleh orang tua, sebab materi sebagai basis utama dari setiap ilmu dan pendidikan selanjutnya.kedua, Memberikan keteladanan sebagai contoh yang baik. Rasulullah adalah sosok panutan yang diutus hanya untuk membawa rahmat dan memperbaiki akhlaq, maka selain aspek taklim aspek ta'dzib juga perlu dipupuk pada anak agar perkembangan otaknya juga berbanding lurus dengan perkembangan afeksi dan psikomotoriknya. Ketiga, menggunakan penyampaian yang mengandung ungkapan kasih sayang. Anjuran berkata baik sangat ditekankan dalam Al-Quran, qaulan sadida, qaulan karima, qaulan ma'rufa, qaulan layyina, qaulan tsaqila dan qaulan maysura.

Sedangkan Andi menjelaskan tanggung jawab orang tua kepada anaknya sebagai berikut pertama, pembinaan dan pendidikan akidah. Anak memiliki fitrah yang perlu dikembangkan, fitrah yang pertama adalah mereka sebagai mahluk yang beragama, jadi potensi religius pertama kali harus berkembang sebelum yang lain berkembang. Sebagai mahluk yang memiliki ruhani-spritual maka tugas orang tua mengembangkan ruhaniyahnya ke arah yang lebih baik. Kedua, pembinaan dan Pendidikan akhlak, dalam hal ini anak perlu didik perilakunya agar menjadi pribadi yang memiliki prilaku yang baik. Karena bagaimanapun anak belajar nilai dan tingkahlaku pada kedua orang tuanya, dalam hal ini sosialisasi primer pertama kali dilakukan oleh kedua orang tuanya. Ketiga, pemeliharaan kesehatan anak. Selain pemeliharaan dan pemantapan ruhani, yang lebih penting lagi pemeliharaan kesehatan. Islam memberi penekanan pada keduanya senagaimana maqolah arab yang sering didengar bahwa al-aqlussalim fi al-jismisssalim. Sehat ruhani dan sehat jasmani harus sama-sama balance, karena secara medis variabel itu saling mempengaruhi antara satu dengan yang lain, oleh karenanya harus diupayakan seoptimal mungkin oleh orang tua. Keempat, pembinaan dan pendidikan intelektual, ranah ini bagian dari ruhaniyah manusia yang peranannya cukup vital dalam aktivitas manusia terutama dalam proses menyerap dan memproduksi pengetahuan. Pada aspek ini pengembangan IQ anak merupakan basis anak untuk 
mengenal banyak hal tentang kehidupan. Kelima, kepribadian dan sosial anak. ${ }^{11}$ merupakan pondasi terakhir sebagai muara dari pendidikan ruhaniyah dan jasadiyah atau pengembangan fitrah-fitrah manusia baik fitrah beragama, berfikir dan berkebudayaan, sehingga cukup kompleks tanggungjawab orang tua pada anaknya.

Dapat disimpulkan bahwa tanggung jawab atau peran utama orang tua yang harus dilakukan adalah memberikan pendidikan mengenai akidah dan dapat mencerminkan contoh perilaku yang baik agar dapat memudahkan dalam mendidik akhlak anak. Ahmad Ustman dalam hal tanggung jawab pendidikan akhlak yang merupakan lanjutan dari pendidikan akidah sebagai berikut:

Pertama, Memberikan contoh kepada anak dalam berakhlak mulia. Orang tua harus lebih dahulu dalam memahami dan mengamalkan kebiasaan perilaku yang baik sehingga dapat mencerminkan akhlak mulia dan dapat menjadi contoh bagi anak-anaknya. Kedua, Menyediakan kesempatan kepada anak untuk mempraktikan akhlak mulia. Anak diberikan hak untuk dapat mempraktekan apa yang sudah kita ajarkan melalui sikap maupun lisan. Ketiga, memberi tanggung jawab sesuai dengan perkembangan anak. Tanggung jawab yang dimaksud bisa berupa pembiasaan dalam beribadah, selalu berpinsip dengan keimanan. Keempat, Mengawasi dan mengarahkan anak agar selektivitas dalam bergaul. Memberikan perhatian pada anak agar terhindar dari perilaku yang menyeleweng dan menjauhkan dari lingkungan yang menimbulkan maksiat.

Orang tua sebagai satuan keluarga juga menjadi pendidikan dasar bagi anak memiliki tanggung jawab untuk mengarahkan anak, menjadi teladan, menanamkan tanggung jawab dan juga memberikan perhatiannya, agar anak dapat terbentuk karakter yang baik sehingga tercermin seorang muslim yang memiliki keutamaan dan kemuliaan sebagaimana cita-cita Islam. ${ }^{12}$

\section{Animasi dan Audio Visual}

Animasi adalah pembuatan gambar atau isi yang berbeda - beda, pada setiap frame, kemudian dijalankan rangkaian frame tersebut menjadi sebuah motion atau

\footnotetext{
11 Andi Syahreni. Tanggung Jawab Keluarga dalam Pendidikan Anak, (Jurnal Bimbingan penyuluhan Islam. 2015), Hal 30-32

12 Muhammad Uzer, Usman. Menjadi Guru Profesional,(Bandung : Remaja Rosdakarya, 1995), hal. 30
} 
gerakan sehingga terlihat seperti sebuah film. ${ }^{13}$ Animasi merupakan bentuk dari sebuah ide atau gagasan yang menjadi sebuah media dalam merepresentasikan sesuatu. Banyak sarana yang digunakan oleh seseorang untuk mengekspresikan keinginan dan ide-idenya. Begitu halnya dengan pembelajaran memanfaatkan animasi sebagai media untuk menyampaikan pengetahuan dan nilai-nilai.

Menurut Darojah media film animasi merupakan media audio-visual berupa rangkaian gambar tidak hidup yang berurutan pada frame dan diproyeksikan secara mekanis-elektronis sehingga tampak hidup pada layar. ${ }^{14}$ Media semacam ini memberikan peran penting dalam proses pembelajaran manusia yang melibatkan dua indrawi yaitu mata dan telinga. Pelibatan dua hal inilah yang menghasilkan pengetahuan baru melalui proses pengindraan.

Mengenai keefektifan dalam memberikan pemahaman mengenai pengetahuan menjelaskan bahwa film animasi jauh lebih efektif bila dibandingkan hanya menggunakan media gambar. ${ }^{15}$ Seorang filosof Konfusius mengatakan bahwa "saat saya mendengar saya lupa, saya melihat saya ingat, saya melakukan kemudian saya paham". Jadi menggabungkan antara proses mendengar dan melihat jauh lebih efektif daripada hanya mendengar atau melihat saja. Proses pengetahuan manusia setidak banyak melibatkan indra manusia.

Sedangkan media audio-visual menurut Yudhi adalah media yang melibatkan indera pendengaran dan penglihatan sekaligus dalam satu proses. Pesan visual yang terdengar dan terlihat itu dapat disajikan melalui program audiovisual seperti film dokumenter, film dokumenter, film drama dan lain-lain. Semua program tersebut dapat disalurkan melalui peralatan seperti film, video, dan juga televisi dan dapat disambungkan pada alat proyeksi. ${ }^{16}$

Jadi perpaduan antara audio visual yang menjadikan suara dan sebagai fungsi utamanya dalam karya-karyanya dengan memadukan animasi yang merupakan kumpulan dari gambar yang berbeda dijalankan dengan rangkaian frame sehingga menjadi sebuah film, akhirnya karya yang ditampilkan akan lebih hidup dan mudah untuk memahami konten yang ada didalamnya.

\footnotetext{
13 Zembry. Animasi web dengan macromedia Flash 8. Jakarta :Elex Media Komputindo 2001 14 Ridan U. Darojah. Peningkatan kemampuan berbicara melaporkan dengan media film animasi pada siswa kelas viii smpn 12 yogyakarta. S1 thesis, uny. 2011

15 Choirunnisa, Keefektifan Media Video Animasi Terhadap Aktivitas Dan Hasil Belajar. Skripsi .2016.

16 Munadi, op.cit., h. 56-57.
} 


\section{Disabilitas}

Menurut Kamus Besar Bahasa Indonesia penyandang diartikan dengan orang yang menyandang (menderita) sesuatu. Sedangkan disabilitas yang berarti cacat atau ketidakmampuan. ${ }^{17}$ Istilah disabilitas berasal dari bahasa inggris dengan asal kata different ability, yang bermakna manusia memiliki kemampuan yang berbeda. Istilah tersebut digunakan sebagai pengganti istilah penyandang cacat yang mempunyai nilai rasa negatif dan terkesan diskriminatif. Istilah disabilitas didasarkan pada realita bahwa setiap manusia diciptakan berbeda. Sehingga yang ada sebenarnya hanyalah sebuah perbedaan bukan kecacatan maupun keabnormalan. ${ }^{18}$

Kata Cacat dan kata berbeda adalah dua hal yang tudak bisa disatukan, namun pada kenyataannya artikulasi ini belum mampu memberi kenyamanan pemaknaan karena sampai detik ini disabilitas tetap diartikan sebagai penyandang cacat. Saat seseorang mendengar kata disabilitas yang muncul dibenaknya adalah cacat. Pemaknaan perbedaan tetap berpiyoratif negatif sehingga kata cacat dan berbeda masih sangat jauh dari pemaknaan yang digunakan oleh publik.

Pada Pasal 1 ayat 1 Undang-Undang Nomor 8 Tahun 2016 Tentang Penyandang Disabilitas disebutkan bahwa "Penyandang disabilitas adalah setiap orang yang mengalami keterbatasan fisik, intelektual, mental dan atau sensorik dalam jangka waktu lama yang dalam berinteraksi dengan lingkungan dapat mengalami hambatan dan kesulitan untuk berpartisipasi secara penuh dan efektif dengan warga negara lainnya berdasarkan kesamaan hak.

Pasal ini menunjukkan bahwa penyandang disabilitas adalah seseorang yang memiliki kekurangan dan keterbelakangan baik fisik maupun mental. Keterbelakangan ini memang perbedan atas kesempurnaan. Namun semua itu merupakan kehendak Allah yang menjadikan perbedaan sebagai rahmat, tentu Allahlah yang mengetahui dan memberi kelebihan atas kekurangannya, sehingga atas dasar ini maka seseorang yang memiliki kesempurnaan sudah sewajarnya ikut membantu memberi kemudahan-kemudahan dalam kehidupannya.

Kemudahan atas disabilitas didorong oleh Pasal 1 ayat 8 Undang-Undang RI Nomor 8 tahun 2016 tentang Penyandang Disabilitas disebutkan bahwa aksesibilitas adalah kemudahan yang disediakan untuk penyandang disabilitas

17 Kamus Besar Bahasa Indonesia.2008.Edisi Ke empat.Jakarta

18 Sugi Rahayu,Utami Dewi dan Marita Ahdiyana. Pelayanan Publik Bidang Transportasi Bagi Difabel di Daerah Istimewa Yogyakarta.(Yogyakarta. 2013), hal 110 
guna mewujudkan kesamaan kesempatan. Kesamaan kesempatan menurut pasal 1 ayat 2 Undang-Undang RI Nomor 8 Tahun 2016 adalah keadilan yang memberikan peluang dan/atau menyediakan akses kepada penyandang disabilitas untuk menyalurkan potensi dalam segala aspek penyelenggaraan negara dan masyarakat.

Pasal ini memberi peluang yang sama bagi para disabilitas tanpa ada diskriminasi sehingga dalam prinsipnya negara menjamin hak-hak kesataraan atas disabilitas, karena itu fasilitasi dan kreasi mereka dianggap sama dengan yang lainnya. Negara tidak membeda-bedakan mereka sebagai warga negara meskipun faktanya mereka memiliki kekurangan, namun dibalik kekurangannya negara tetap memperhatikan kemampuannya.

\section{Metode}

Penulis dalam penelitian ini menggunakan metode kualitatif yang merupakan penelitan berbasis pada kajian pustaka dengan maksud menyajikan beberapa pendapat yang diolah dan dijelaskan kembali sehingga dapat menghasilkan paparan yang dapat membantu memecahkan masalah yang ada pada masyarakat.

Setelah mendapatkan data dari beberapa referensi yang relevan, kemudian data tersebut diolah dengan menganalisis isi yaitu untuk mendapatkan esensi dari kata berupa meaning di dalam teks mati tersebut. Teknik analisis yang digunakan yakni menggunakan teori semiotika milik Ferdinand de Saussure.

Sumber primer atau subjek data penelitian ini merupakan literatur dari beberapa buku dan karya tulis ilmiah. Sedangkan objek atau sumber sekundernya adalah film animasi Nussa dari 3 episode yang berjudul: Di Rumah Saja, Ingin Seperti Umma dan Nussa Bisa.

\section{Hasil \& Diskusi}

\section{Semiotika Pada Film Animasi Nussa}

Tanda merupakan hal utama dalam filsafat kebudayaan, dalam hal ini Ferdinand Saussure menjelaskan tanda terdiri dari Bunyi/suara dan gambar yang disebut Signifier. Sedangkan hal lain dari tanda itu ada konsep dan makna yang disebut Signified. Jadi dalam semiotika Ferdinand Saussure bahwa sistem tanda merupakan prinsip dari bahasa, yang setiap tanda terdapat dua bagian yaitu signifier (penanda) dan signified (penanda). Bahasa yang dimaksud bisa bersumber dari suara manusia, binatang ataupun bunyi sebuah benda, karena ia menjelasakan 
diartikan sebagai bahasa manakala suara atau bunyi tersebut dapat menyatakan, mengekspresikan dan menyampaikan ide, makna atau pengertian tertentu. ${ }^{19}$

Semiotika Ferdinand Saussure dijadikan pisau bedah untuk mengungkap nilai-nilai Islami yang bersembunyai dibalik teks atau gambar-gambar yang berbunyi. Peran pendidikan orang tua terhadap anaknya dapat dilihat pada proses interaksi langsung di mana ada kehangatan komunikasi dan pertukaran makna antar keduanya. Dapat diungkapkan bahwa Nussa sebagai anak difabel dalam film animasi Nussa dari beberapa episode sebagai berikut:

\section{Episode Nussa di Rumah saja}

Pertama, adegan dalam film ini yaitu menasehati anak untuk bersyukur pada durasi 03:14-03:2820 untuk lebih jelasnya bisa dilihat pada gambar di bawah ini:

\section{Gambar 1.a}

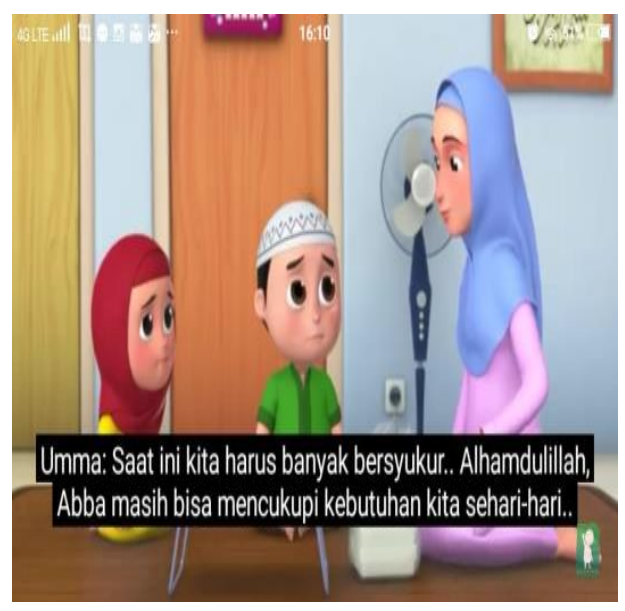

Pada gambar 1.a sebagai penanda yaitu gambar seorang ibu berkomunikasi dengan kedua anak-anaknya, terlihat kehangatan antar keduanya yang dibalut dengan busana Islami dan susana kesederhanaan dan teks, Umma berkata: "saat ini kita harus banyak bersyukur, alhamdulillah Abba masih bisa mencukupi kebutuhan kita sehari-hari". Dari kalimat tersebut maka terdapat penanda yaitu orang tua mengajak anak agar bersyukur telah diberikan kecukupan dalam hal rezeki.

19 Alex Sobur. Semiotika Komunikasi.Bandung, (Remaja Rosda karya, 2016), Hal. 64 20 Sumber: Faishal Abyan, film animasi Nussa, 20 Oktober 2020, Nussa Official. 
Dari gambaran tersebut bahwa ada makna yaitu Mengajarkan anak bersyukur merupakan langkah untuk menyempurnakan akidah anak. ${ }^{21}$ Ajaran akidah dalam keluarga adalah pondasi bagi anak untuk menapaki kehidupan yang lebih luas lagi. Bersyukur sangat dianjurkan dalam Islam sehingga ajaran religius bersyukur ini adalah karakter beragama yang harus diinternalisasikan oleh orang tua kepada anakanya.

Peran Orang tua dalam memberikan pendidikan mengenai aqidah sudah dibahas dalam tafsir Al Misbah karya Quraish Shihab. Dalam mendidik anak yang wajib dilakukan oleh orang tua pertama, memberikan pendidikan Aqidah. Kedua, memberikan teladan dan pendidikan berupa akhlakul karimah. Ketiga, menggunakan bahasa yang mengukapkan rasa kasih sayang.

Kedua, Adegan dalam film ini yaitu ${ }^{22}$ mendidik anak dalam mengamalkan nilai islam pada durasi 05:10-05:5723 untuk lebih jelasnya bisa dilihat pada gambar di bawah ini:

\section{Gambar 1.b}

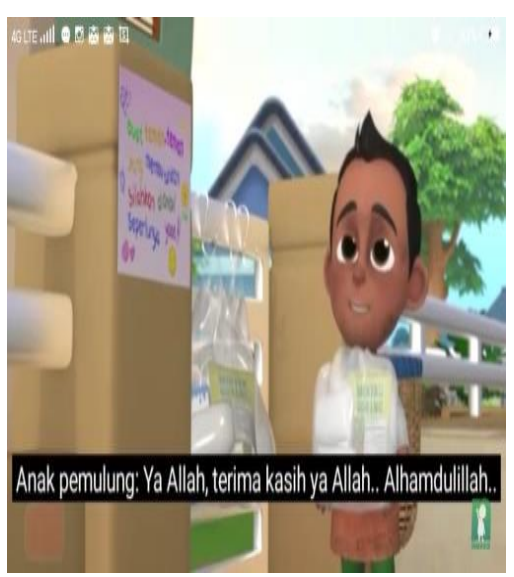

Pada Gambar 1.b sebagai penanda yaitu gambar yang berisi seorang anak yang menggendong sampah sebagai penghasilannya dan teks yang berbunyi Anak pemulung berkata: "Ya Allah, terimakasih ya Allah". Dari penanda itu maka yang menjadi penanda Nussa dan Rara mempraktekan bentuk syukur dengan berbagi terhadap sesamanya.

Memberikan kesempatan bagi anak agar dapat mengamalkan apa yang sudah dipelajarinya merupakan tugas orang tua dalam membiasakan dan mendidik anak.

21 Shabra S. Mensyukuri Nikmat Allah Akan Menyempurnakan Tauhid. 2014

22 Sumber: Faishal Abyan, film animasi Nussa, 20 Oktober 2020, Nussa oficial 23Sumber: Faishal Abyan, film animasi Nussa, 20 Oktober 2020, Nussa oficial 
Pembiasan baik yang diulang-ulang (habit) akan menghasilkan karakter yang baik, karakter itu yang pada akhirnya akan membentuk keperibadian yang baik. Metode pembiasaan di dalam pendidikan Islam sangat dianjurkan terutama pada pembentukan tingkah laku. Banyak ajaran agama yang membutuhkan pembiasaan, agar dari pembiasaan itu dapat mendatangkan hal lain selain kerakter yaitu karomah, jika sesuatu dilakukan secara istiqomah makan dapat mendatangkan karomah.

Jadi ajaran agama butuh diamalkan sebagaimana trilogi ajaran Islam yaitu iman, Islam dan ihsan, iman, ilmu dan amal sholeh. Semakin banyak pengamalan agama dalam individu pemeluknya maka akan menghasilkan kecerdasan individual dan kecerdasan sosial. Sehingga agama menjadi lokomotif seseorang untuk melakukan berbagai perubahan-perubahan dalam kehidupan.

\section{Episode Ingin Seperti Umma}

Adegan pada film ini yaitu Orang tua memberikan teladan untuk anaknya pada durasi 00:35-00:4824 untuk lebih jelasnya bisa dilihat pada gambar di bawah ini:

\section{Gambar 2.a}

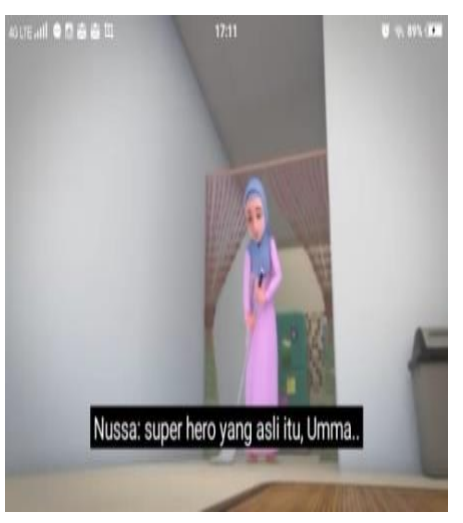

Pada Gambar 2.a sebagai penanda yaitu gambar yang berisi tentang seorang ibu sedang menyapu rumahya sedangkan penanda teks teks berbunyi Nussa berkata: "Super hero yang asli itu, Umma". Dari itu maka ini menjadi penanda bahwa sebagai orang tua, Umma memberikan teladan kepada anaknya mengenai kebersihan dan keikhlasan.

${ }^{24}$ Sumber: Faishal Abyan, film animasi Nussa, 20 Oktober 2020, Youtube: Nussa oficial 
Keteladanan dalam memberikan pendidikan kepada anak merupakan hal yang harus dilakukan oleh kedua orang tua karena hal ini yang akan memudahkan dalam memberikan nasihat agar berprilaku baik. Dalam pendidikan Islam dikenal dengan metode suri teladan. Dalam metode umum dikenal dengan metode demonstrasi yaitu metode yang diperagakan dalam hal ini cocok dengan apa yang dikatakan oleh seorang konfusius bahwa "saya melihat saya ingat", oleh karena itu orang tua perlu membangun ingatan-ingatan yang baik pada anak-anaknya dengan memberi tindakan-tindakan secara Islami sebagaimana terdapat pada gambar tersebut.

\section{Episode Nussa Bisa}

Adegan pada film ini yaitu ibu memberikan perhatian terhadap Nussa pada durasi 01:05-01:13 untuk lebih jelasnya bisa dilihat pada gambar di bawah ini :

\section{Gambar 3.a}

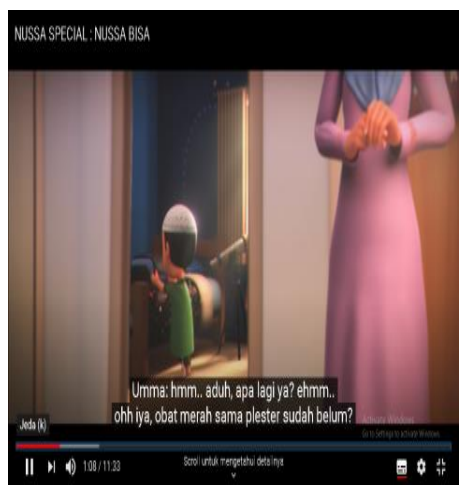

Pada gambar 3.a dapat dijelaskan bahwa sebagai Penanda berupa Gambar yang berisi Seorang ibu sedang memperhatikan anaknya sedang melipat pakaian dan Teks yang berbunyi Umma berkata: "Nussa, handuk sama baju untuk gantinya jangan lupa dibawa ya". Maka sebagai penanda sosok ibu lebih dominan dengan perasaan dalam memperhatikan Nussa sebagai anaknya.

Kedua orang tua memang berbeda dalam mendidik anak-anaknya, sebagai mana sifat perempuan sebagai mahluk perasa maka dalam mendidik anak-anaknya ibu lebih banyak menggunakan pendekatan perasaan dalam mendidik anakanaknya. Di sini jelas pendidikan kasih sayang lebih dominan dari pada pendidikan nalar. Maka ada alasan yang kuat jika anak jauh dari kedua orang tuanya atau lebih khusus ditinggal oleh ibunya maka besar kemungkinan anak menjadi liar karena 
kurang mendapatkan pendidikan kasih sayang dari ibunya. Jadi orang tua memiliki peran vital dalam mengawasi dan memperhartikan anaknya.

Adegan film selanjutnya yaitu kedua orang tua melihat kondisi anaknya 01:55-03:1825. Untuk lebih jelasnya bisa dilihat pada gambar di bawah ini :

\section{Gambar 3.b}

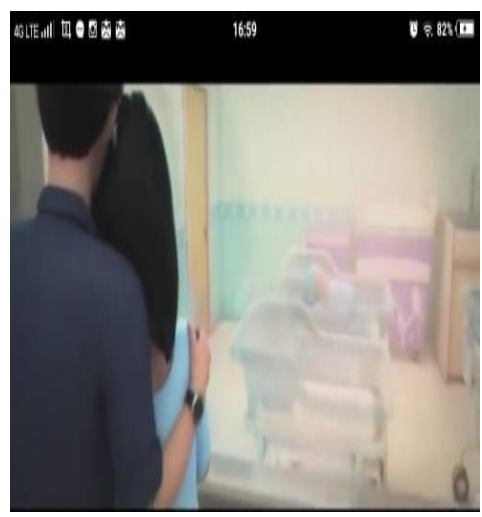

Pada gambar 3.b dijelaskan bahwa penanda terdapat pada gambar yang berisi kedua orang tua sedang melihat bayinya di dalam ruang NICU (neonatal intensive care unit) dan bunyi dengan suara tangisan dari ibu Nussa. Dari hal tersebut maka penandanya Ibu Nussa menangis karena melihat anaknya yang terlahir sebagai tuna daksa. Dalam penelitian ini diungkapkan bahwasanya tokoh utama yakni Nussa lahir sebagai anak difabel ia digambarkan dengan tidak mempunyai kaki sebelah kiri.

Konten kreator dari Nussa juga menjelaskan bahwa ia sengaja mendesain Nussa sebagai difabel dengan alasan atau pesan "how to become perfect with imperfection" yang artinya bagaimana agar bisa menjadi sosok yang sempurna dengan ketidaksempurnaan, di sinilah penanaman percaya diri dibutuhkan. Dalam akun official-nya di instagram juga memberikan alasan agar anak difabel lebih semangat lagi dalam kehidupan. ${ }^{26}$ Dari keterbatasan itu menjadi kemampuan dan dari keterbelakangan menjadi yang terdepan dan dari ketidaksempurnaan menjadi sebuah kelebihan. Di sini tampak spirit hidup bahwa meskipun ada kekurangan bukan berarti menjadi penghalang, namun kekurangan itu dapat menjadi penyemangat untuk memberikan yang terbaik dalam kehidupan.

\footnotetext{
25 Sumber: Faishal Abyan, film animasi Nussa, 20 Oktober 2020, Youtub:Nussa oficial 26 Raja Insani. Mengapa Nussa Diciptakan Berkaki Palsu? Inilah Alasan Kreator. https://akhbar.bersamadakwah.net/
} 


\section{Kesimpulan}

Melalui teori analisis semiotika Ferdinand de Saussure mengenai film animasi Nussa tersebut terdapat berbagai macam gambaran mengenai peran orang tua yang tidak terlepas dari nilai islami seperti menanamkan aqidah dengan mengajarkan anak bersyukur kepada Allah yang maha memberikan rezeki, memberikan kesempatan anak mengamalkan ilmu yang telah dipelajari, menjadi teladan dalam mencontohkan perilaku dan akhlak yang baik, selain itu penelitian ini mengungkapkan bahwa tokoh utma dari film animasi Nussa merupakan anak difabel dengan menyelipkan makna bagimana agar kekurangan dan ketidaksempurnaan dapat menjadi seorang yang mempunyai pengaruh "how to become perfect with imperfection". Dalam bahasa sederhana bagaimana seseorang menjadi orang yang lebih percaya diri dalam hidupnya.

\section{Referensi}

Astita, Wida,2016. Peran Orang Tua Dalam Mendidik Akhlak Anak Di Desa Bangun Jaya Kecamatan Sungkai Utara Lampung Utara. Lampung Jurusan Pendidikan Agama Islam.Lampung:IAIN Raden Intan

Cahyati, Nika, 2020. Peran Orang Tua Dalam Menerapkan Pembelajaran di Rumah Saat Pandemi Covid 19. Jurnal Golden Age, Universitas Hamzanwadi, 04(1)

Chandler, Daniel,2007. Semiotics The Basics, Perancis: Taylor \& Francis e-Library, Cet. II

Darojah, R. U. 2011. Peningkatan Kemampuan Berbicara Melaporkan dengan Media Film Animasi pada Siswa Kelas VIII SMPN 12 Yogyakarta. Skripsi. UNY

Fakhriyatus. 2020. Dan Moral Pada Masapandemidi Tk Al-Hidayah Lumajang. Jurnal Pengembangan Nilai agama dan moral.

https://www.worldometers.info/coronavirus. (worldometer.info diakses pada $26 / 12 / 2020$

Muhammad Uzer, Usman, 1995.Menjadi Guru Profesional,.Bandung : Remaja Rosdakarya,

Munadi, Yudhi.2012.Media Pembelajaran; Pembelajaran Sebuah Pendekatan Baru. Jakarta: Gaung Persada Press.

Poerwadarminta.1991. Kamus Besar Bahasa Indonesia, Jakarta : Balai Pustaka 
Raja Insani.. (2018, Desember 04). Mengapa Nussa Diciptakan Berkaki Palsu?

Inilah Alasan Kreator.. https://akhbar.bersamadakwah.net/

Shabra S. (2014, Oktober 21). Mensyukuri Nikmat Allah Akan Menyempurnakan

Tauhid.. https://fimadani.com/

Sobur, Alex Semiotika Komunikasi.Bandung:Remaja Rosda karya. 2016.

Soejono, Soekamto. 1990. Sosiologi Suatu Pengantar, Jakarta : CV. Rajawali Press.

Soekamto, Soejono, 1990.Sosiologi Suatu Pengantar, Jakarta : CV. Rajawali Press

Sugi Rahayu,Utami Dewi \& Marita Ahdiyana,2013. Pelayanan Publik Bidang Transportasi Bagi Difabel di Daerah Istimewa Yogyakarta.Yogyakarta

Syahreni, Andi. 2015. Tanggung Jawab Keluarga dalam Pendidikan Anak, Jurnal Bimbingan penyuluhan Islam.

Syahreni. Andi,2015.Tanggung Jawab Keluarga dalam Pendidikan Anak, (Jurnal Bimbingan penyuluhan Islam

Undang-Undang Nomor 8 Tahun 2016 Tentang Penyandang Disabilitas

Usman, Samad. 2015. Tanggung Jawab Orang Tua Terhadap Pendidikan Anak Dalam Perspektif Islam. Jurnal Pndidikan Anak.

Vaerdiansyah. 2004. Pengantar Ilmu komunikasi. Jakarta: PT Grasindo.

Van Zoest,1990. Fiksi dan Non-fiksi dalam kajian semiotik. Jakarta: Inter masa.

Wibowo, Indiwan Seto Wahyu, 2013. Semiotika Komunikasi - Aplikasi Praktis Bagi Penelitian Dan Skripsi Komunikasi, Jakarta : Penerbit Mitra Wacana Media

Wikipedia. 2020. Difabel. September 24. https://id.wikipedia.org/wiki

World Health. Disability. https://www.who.int/health-topics/disability

Zembry. 2001. Animasi Web dengan Macromedia Flash 8. Jakarta: Elex Media Komputindo, 